\title{
TANGGUNG JAWAB SOSIAL BANK SYARIAH TERHADAP STAKEHOLDER DALAM PERSPEKTIF MAQÂSHID SYARI'AH
}

\author{
Siti Amaroh \\ Jurusan Syariah dan Ekonomi Islam, STAIN Kudus \\ Jl. Conge Ngembal Rejo No.51, Kota Kudus, Jawa Tengah 59322 \\ E-mail: amar_stainkudus@yahoo.co.id
}

\begin{abstract}
Sharia Bank's Social Responsibility to Stakeholder in the Perspective of Maqâshid Syarî‘ah. The implementation of social responsibility is not solely to meet the expectations of the public, but as a form of devotion to Allah. Good values in social responsibility are shown for the formation of a physically and morally prosperous society, as well as to achieve happiness ( $f \hat{a} l a \underline{h}$ ) in the world and the hereafter. Activities of Islamic banks is not only to maximize financial profit but also to achieve social welfare as an effort to fulfill the maqâshid syarîah. Therefore, a policy of social responsibility of Islamic banks should be legally integrated in their operational systems and as an obligatory mandate to optimize achievement.
\end{abstract}

Keywords: social responsibility, maqâshid syarî‘ah, Islamic banks

\begin{abstract}
Abstrak. TanggungJawab Sosial Bank Syariab Terhadap Stakeholder dalam Perspektif Maqâshid Syarî'ah. Tanggung jawab sosial diimplementasikan tidak semata-mata untuk memenuhi harapan publik tetapi sebagai bentuk ketakwaan kepada Allah Swt. Nilai-nilai kebaikan dalam tanggung jawab sosial ditujukkan bagi terbentuknya masyarakat yang sejahtera secara fisik dan moral, serta untuk mencapai kebahagiaan (fâlah ) dalam tatanan kehidupan dunia dan akhirat. Kegiatan bank syariah tidaklah semata-mata untuk memaksimalkan keuntungan finansial tetapi juga untuk mewujudkan kesejahateraan sosial sebagai upaya pemenuhan terhadap maqâshid syarîah. Oleh karena itu maka kebijakan tanggung jawab sosial bank syariah harus terintegrasi secara sah dengan sistem operasionalnya dan sebagai mandat wajib sehingga optimal dalam pencapaiannya.
\end{abstract}

Kata kunci: tanggung jawab sosial, maqâshid syarî̀ah, bank syariah

\section{Pendahuluan}

Tujuan akhir sistem ekonomi Islam adalah sebagaimana tujuan dari syariat Islam itu sendiri (maqâshid syarîa $a$ ) yaitu mencapai kebahagiaan di dunia dan akhirat (falâh) melalui suatu tatanan kehidupan yang baik dan terhormat (hayâh thayyibah) ${ }^{1}$. Setiap individu dalam kehidupan Islam mengacu pada nilai-nilai keseimbangan tersebut termasuk dalam menjalankan transaksi keuangan. Bank syariah dikembangkan agar kegiatan transaksi keuangan dan investasi sesuai dengan prinsip syariat Islam.

Bank syariah merupakan lembaga keuangan yang menjalankan fungsi intermediasi keuangan terutama ditujukan bagi masyarakat luas agar transaksi keuangan yang dipilih sesuai dengan prinsip-prinsip Islam. Dalam

Naskah diterima: 25 Juli 2015, direvisi: 3 Agustus 2015, disetujui untuk terbit: 20 September 2015.

1 Munrokhim Misanam, Priyonggo Suseno, dan M. Bhekti Hendrieanto, Ekonomi Islam, (Jakarta: PT. Raja Grafindo Perkasa, Jakarta, 2008), h. 54. implementasinya, sistem perbankan berbasis syariat Islam ini telah berekspansi secara luas dipelbagai negara termasuk di negara-negara barat.

Tujuan pendirian bank syariah tidak semata-mata memaksimalkan profit sebagaimana pada tujuan sistem keuangan berbasis kapitalistik, tetapi pada tujuan yang holistik. Tujuan tersebut dapat dicapai ketika bank syariah berperan melalui beberapa tindakan, yaitu: (1) berkontribusi pada kesejahteraan sosial (social welfare); (2) berpartisipasi aktif dalam upaya penghapusan kemiskinan (poverty alleviation); dan (3) melakukan kegiatan sosialisasi dan edukasi secara internal dan eksternal (masyarakat) agar dapat menjalankan nilai-nilai keislaman sebagai panduan dalam kehidupan sosial dan ekonomi ${ }^{2}$.

Bank syariah dilihat dari sisi aset telah berkembang

\footnotetext{
${ }^{2}$ Asyraf Wajdi Dusuki, "Understanding the Objectives of Islamic Banking: a Survey of Stakeholders' Perspectives", International Journal of Islamic and Middle Eastern Finance and Management, Vol. 1, No. 2, (2008), h 138.
} 
cukup pesat dengan perkiraan pertumbuhan sebesar US $\$ 1,7$ triliun pada tahun 2013 atau meningkat sebesar $17,6 \%$ selama 4 tahun terakhir dengan kemampuan menghasilkan laba sebesar $12,6 \%{ }^{3}$. Kinerja tersebut diprediksi akan terus meningkat seiring dengan minat masyarakat terhadap bank syariah. Namun demikian masih ada sejumlah isu penting yang melekat pada tujuan pendirian bank syariah yaitu: (1) bagaimana nilai-nilai tanggung jawab sosial bank syariah yang harus dilaksanakan dalam pencapaian tujuan holistik; dan (2) bagaimana tanggung jawab sosial bank syariah menurut perspektif maqâshid syarîah sebagai nilai-nilai fundamental yang mendasari tata kelola bank syariah. Tulisan ini mengkaji secara mendalam tentang tanggung jawab sosial bank syariah terhadap stakeholder menurut maqâshid syarîah.

\section{Nilai-Nilai Fundamental Bank Syariah}

Bank syariah didirikan dengan tujuan mulia didasarkan pada nilai-nilai fundamental yang tercantum dalam Alquran. Oleh karena itu, untuk memahami bank syariah secara menyeluruh maka harus mengetahui filosofinya. Filosofi bank syariah dilandaskan pada nilai-nilai fundamental menurut prinsip-prinsip Islam yang bersumber dari Alquran dan Sunah yang termanifestasikan pada prinsip dan nilai-nilai sebagai berikut:

Pertama, prinsip bagi hasil. Prinsip bagi hasil dapat dicapai melalui bentuk-bentuk kegiatan partnership atau syirkah dengan membagi keuntungan dan kerugian antara pemilik dana (shâh $\underline{i b}$ al-mâl) dan pengelola dana (mudhârib). Produk bank syariah yang didasarkan pada prinsip bagi hasil antara lain pada produk-produk dengan akad mudhârabah dan musyârakah. Dengan sistem tersebut, bank menerima pembagian keuntungan yang dihasilkan dari usaha yang telah dikelola bersama. Prinsip bagi hasil disebutkan dalam Alquran Surah alNisâ’ (4): 29 sebagai berikut:

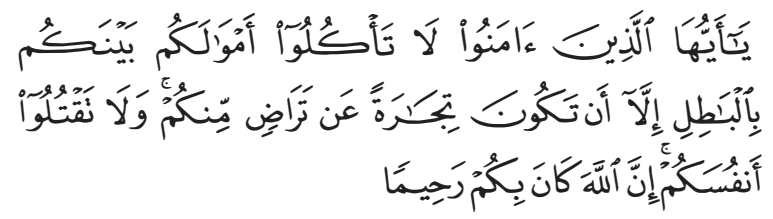

Hai orang-orang yang beriman, janganlah kamu saling memakan harta sesamamu dengan jalan yang batil, kecuali dengan jalan perniagaan yang berlaku dengan suka sama-suka di antara kamu dan janganlah kamu membunuh dirimu; Sesungguhnya Allah adalah Maha Penyayang kepadamu.

Prinsip bagi hasil disebut sebagai prinsip otentik dari sistem keuangan Islam karena relevan dan konsisten dengan

\footnotetext{
${ }^{3}$ World Islamic Banking Competitiveness Report 2013-2014, h. 8.
}

sistem nilai dan moral ekonomi Islam dan sekaligus dapat dikembangkan pada sistem ekonomi modern ${ }^{4}$.

Kedua, pelarangan riba. Bank syariah bergerak pada sektor riil, tidak mengizinkan adanya eksploitasi, dan melarang penghimpunan dan penyaluran dana yang mengandung unsur riba. Meskipun perdebatan tentang riba masih terus berlangsung dengan pelbagai argumentasi, namun secara eksplisit pelarangan riba telah tercantum dalam Alquran Surahh Ali Imran (3): 130 sebagai berikut:

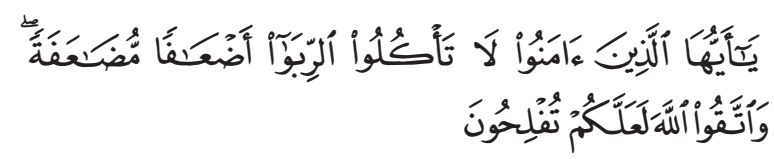

Hai orang-orang yang beriman, janganlah kamu memakan riba dengan berlipatganda dan bertakwalah kamu kepada Allah supaya kamu mendapat keberuntungan.

Ayat-ayat lain yang menerangkan tentang larangan riba terdapat dalam Q.s. al-Baqarah (2): 275 yang menjelaskan bahwa "meskipun nampak terdapat keuntungan riba dan dari perdagangan, namun hanya hasil keuntungan dari perdagangan saja yang diperbolehkan". Riba dilarang karena dapat menghapus keridaan Allah Swt. terhadap harta tersebut karena ada bagian yang diambil dari harta orang lain 5 . Selain itu riba dapat mengarahkan pengambilan keuntungan dengan cara-cara yang tidak sah yang tidak hanya dalam bentuk bunga tetapi dapat pula dalam bentuk yang lain seperti ketidaksamaan nilai-nilai timbangan dan penggelembungan modal. Pelarangan bunga sebagai salah satu bentuk riba menempatkan bank syariah sebagai fasilitator dalam menciptakan kesejahteraan dan juga sebagai bentuk pembentukan sistem keuangan yang inklusif dalam rangka membangun kehidupan yang hakiki yaitu keseimbangan kehidupan material dan spiritual. Allah Swt. memberikan solusi terhadap terhadap kreditur atas debitur yang dalam kesulitan untuk mengembalikan pinjamannya dalam Q.s. al-Baqarah (2): 278-279 dengan cara: (1) memberikan tenggang waktu sampai debitur mampu untuk membayar; (2) tidak membebankan tambahan pinjaman (riba) melainkan pokok harta/pinjaman saja; dan (3) memperlakukannya sebagai amal (charity) ${ }^{6}$.

\footnotetext{
4 Ibrahim Warde, Islamic Finance: Keuangan Islam dalam Perekonomian Global, diterjemahkan oleh Andriyadi Ramli, (Yogyakarta: Yogyakarta 2009), h. 289

${ }^{5}$ Riba dalam pertanyataan di atas ialah riba nasiah. Sebagian besar ulama menjelaskan bahwa riba nasiah itu selamanya haram, walaupun tidak berlipat ganda. Riba itu ada dua macam: nasiah dan fadhl. Riba nasiah ialah pembayaran lebih yang disyaratkan oleh orang yang meminjamkan. Riba fadhlialah penukaran suatu barang dengan barang yang sejenis, tetapi lebih banyak jumlahnya karena orang yang menukarkan mensyaratkan demikian, seperti penukaran emas dengan emas, padi dengan padi, dan sebagainya. Riba yang dimaksud dalam ayat ini adalah riba nasiah yang berlipat ganda yang umum terjadi dalam masyarakat Arab zaman Jahiliyah

${ }^{6}$ Sirajo Aliyu, 2014 , "Sustainable Islamic Banking: A Conceptual
} 
Ketiga, tidak adanya unsur gharâr dan maysir. Gharâr secara etimologi berarti penipuan, penyesatan, segala sesuatu yang dapat membahayakan, atau segala sesuatu yang masih bersifat ambigu dalam hubungan kontraktual ${ }^{7}$. Gharâr juga dapat berarti risiko atau ketidakpastian. Praktik gharâr dilarang namun pengambilan risiko tidak dilarang karena risiko adalah segala sesuatu yang tidak dapat dihindari dalam kegiatan perdagangan. Pelarangan praktik-praktik gharâr diterangkan dalam Alquran Surah Al-Mầidah (5): 90 sebagai berikut:

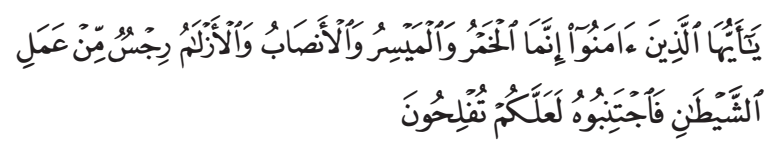

Hai orang-orang yang beriman, sesungguhnya (meminum) khamar, berjudi, (berkorban untuk) berhala, mengundi nasib dengan panah, adalah termasuk perbuatan setan. Maka jauhilah perbuatan-perbuatan itu agar kamu mendapat keberuntungan.

Gharâr dalam bank syariah dapat terjadi pada transaksi yang belum jelas atau pada situasi dan kondisi yang belum pasti. Praktik gharâr dapat terjadi pada kegiatan yang mengandung perjudian (maysir) karena adanya unsur untung-untungan, dan juga pada praktikpraktik usaha yang mengandung alkohol (khamr).

Keempat, eksistensi Dewan Pengawas Syariah. Berbeda dengan institusi keuangan lainnya, bank syariah juga memiliki penasihat yang berkaitan dengan ketetapan syariat Islam (in-house religious advisers) yaitu Dewan Pengawas Syariah (DPS). Arti penting keberadaan Dewan Pengawas Syariah ini mengacu pada firman Allah Swt. dalam Alquran Surah Al-Mẩidah (5): 8 sebagai berikut:

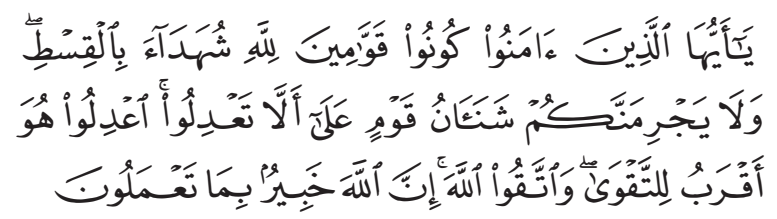

Hai orang-orang yang beriman hendaklah kamu jadi orang-orang yang selalu menegakkan (kebenaran) karena Allah, menjadi saksi dengan adil, dan janganlah sekalikali kebencianmu terhadap sesuatu kaum, mendorong kamu untuk berlaku tidak adil. Berlaku adillah, karena adil itu lebih dekat kepada takwa, dan bertakwalah kepada Allah, sesungguhnya Allah Maha Mengetahui apa yang kamu kerjakan.

Dewan Pengawas Syariah (DPS) merupakan ahli dan saksi dalam pengelolaan bank syariah yang berperan melalui pernyataan-pernyataan bahwa seluruh transaksi keuangan yang dilakukan oleh bank syariah telah sah

Framework for Non-Interest Banks in Nigeria", International Journal of Economics, Management, and Accounting Vol. 22, No. 1, (2014), h. 49 7 Saiful Azhar Rosly dan Mohammad Ashadi Zaini, 2008, "RiskReturn Analysis of Islamic Banks' Investment Deposits and Shareholders' Fund", Managerial Finance, Vol. 34, No. 10, (2008) h. 695 dan sesuai dengan syariat Islam ${ }^{8}$. Keberadaan DPS juga mengurangi informasi asimetris (tidak berimbang) yang menjadi penyebab kurangnya pengetahuan nasabah tentang produk dan pengelolaan bank syariah. Dengan demikian maka masyarakat dapat terjamin keamanannya dalam melakukan transaksi perbankan syariah. Lembaga tersebut memiliki independensi dalam sikap pemikiran yang tidak bergantung atau tidak tunduk pada pengaruh dan tekanan kepentingan yang saling bertolak belakang dan harus berpegang teguh pada peraturan dan nilainilai religiusitas Islam.

\section{Tujuan Holistik Bank Syariah}

Fokus utama sistem keuangan konvensional terletak pada aspek transaksi ekonomi dan keuangan, sedangkan sistem keuangan Islam menekankan pada aspek moral, sosial, dan dimensi religiositas dengan tujuan untuk meningkatkan kesetaraan pada masyarakat. Adapun persamaan kedua sistem terdapat pada fungsinya dalam membantu sistem pembayaran (payment system) dalam sebuah negara dan sekaligus sebagai lembaga intermediasi keuangan.

Salah satu tujuan Islam adalah merealisasikan keadilan bagi manusia dengan mana keadilan itu dicapai melalui seperangkat nilai-nilai moralitas yang diterima oleh setiap orang dan diyakini dengan sepenuh hati ${ }^{9}$. Demikian pula pada sistem keuangan Islam haruslah dapat menerapkan nilai-nilai keadilan yang menciptakan stabilitas pada masyarakat berdasarkan nilai-nilai moralitas Islam. Wahbah al-Zuhaylî dalam bukunya, al-Fiqh alIslâmî wa-Adillatuh, menyatakan bahwa "tujuan utama lembaga keuangan Islam bukanlah untuk menghasilkan laba (profit-making), tetapi lebih kepada pemberian dukungan terhadap pengembangan kehidupan sosial ekonomi dan penghapusan kemiskinan"10.

Bank syariah didirikan bukanlah sebagai lembaga amal melainkan sebagai lembaga ekonomi yang tetap memiliki tujuan untuk mendapatkan keuntungan. Namun, tujuan memaksimalkan profit bukanlah tujuan satu-satunya dengan mengabaikan tujuan lainnya. Tujuan bank syariah selain mendapatkan keuntungan adalah pencapaian tujuan yang holistik sesuai dengan nilainilai keislaman bagi tercapainya tujuan-tujuan sebagai

\footnotetext{
${ }^{8}$ Rifaat Ahmed Abdel Karim, "The Independence of Religious and External Auditors: The Case of Islamic Banks," Accounting Auditing and Accountability Journal, 3, (1990), h. 33.

${ }^{9}$ M. Umer Chapra, 2009, The Global Financial Crisis Can Islamic Finance Help? Insight 01: 4, h. 31.

${ }^{10}$ Asyraf Wajdi Dusuki, "Understanding the Objectives of Islamic Banking: a Survey of Stakeholders' Perspectives”, International Journal of Islamic and Middle Eastern Finance and Management, Vol. 1, No. 2, (2008), h. 136.
} 
berikut ${ }^{11}$ : Pertama, memberikan kontribusi sosial melalui kebijakan investasi yang merepresentasikan kebutuhan masyarakat sehingga membantu mensukseskan pembangunan ekonomi bangsa. Bank syariah dapat memberikan prioritas bagi kebutuhan mendasar seperti pangan, papan, dan kesehatan terutama bagi masyarakat yang memiliki keterbatasan akses ekonomi melalui programprogram berbiaya rendah.

Kedua, menciptakan peluang pekerjaan yang terfokus pada sektor-sektor perekonomian yang memiliki nilai tambah dan mendukung pencapaian tujuan pembangunan nasional. Peluang kerja dapat dilakukan melalui pembiayaan pada sektor riil seperti pertanian, industri, dan aktivitas padat karya.

Ketiga, mempromosikan dan menstimuli jiwa kewirausahaan melalui produk-produk pembiayaan dengan prinsip bagi hasil yang ditujuan pada usaahausaha kecil dan menengah.

Keempat, keadilan sosial, kesetaraan, dan penghapusan kemiskinan yang dilakukan melalui kegiatan penghimpunan dan distribusi zakat kepada kelompok miskin dan pihak-pihak yang berhak menerima. Selain itu bank syariah dapat memberikan pinjaman kebajikan (qard al-hasan), yaitu pinjaman tanpa dikenai biaya.

Untuk mencapai keadilan sosial yang menghapus problematika masyarakat yang kompleks maka bank syariah harus dapat berperan sebagai perantara keuangan yang adil. Sistem bagi hasil merupakan cara yang tepat agar setiap pihakyang terlibat memahami bahwa didalam kegiatan perniagaan maka terdapat risiko yang harus dipahami dan sangat dimungkinkan berakibat pada kerugian. Oleh karena itu, baik pemilik dana maupun pengelola harus menjalankan perniagaannya dengan prinsip kehati-hatian, memperhatikan efektivitas, dan senantiasa melakukan kegiatan pengawasan.

\section{Tanggung Jawab Sosial Bank Syariah}

Bank dan lembaga keuangan berperan penting dalam melaksanakan tanggung jawab sosial. World Bank menjelaskan tanggung jawab sosial memberikan kontribusi pada pengembangan ekonomi yang berkelanjutan (sustainable economic development) karena kegiatan tersebut melibatkan komunitas-komunitas pada masyarakat lokal sehingga dapat membantu memperbaiki kualitas hidup masyarakat setempat ${ }^{12}$. h. 9 .

${ }^{11}$ Bernard Lewis, Islam and West, (Oxford University Press, 1993),

${ }^{12}$ Md Habib-Uz-Zaman Khan, Abdel K. Halabi, and Martin Samy, "Corporate Social Responsibility (CSR) Reporting: a Study of Selected Banking Companies in Bangladesh, Social Responsibility Journal, Vol. 5, No. 3, (2009), h. 345.
Islam merupakan code of life yang lengkap dengan nilainilai fundamental yang mendasarinya yaitu keyakinan dan keimanan ('aqîdah), ibadah, serta moralitas dan etika $(a k b l a \hat{q})^{13}$. Segala sesuatu yang ada di muka bumi merupakan ciptaan Allah Swt. sehingga manusia memiliki tanggung jawab untuk menjaga amanah (tanggung jawab) tersebut. Demikian pula dalam kegiatan ekonomi dan bisnis, setiap tindakan dalam menghasilkan output harus disertai dengan implementasi tanggung jawab terhadap diri dan lingkungannya.

Konsep tanggung jawab sosial dalam Islam mencakup makna yang luas dan tidak sekadar untuk memenuhi harapan publik tetapi sebagai bentuk ketakwaan kepada Allah Swt. ${ }^{14}$ Hubungan manusia dan penciptanya melalui tanggung jawab sosial merupakan bentuk internalisasi nilai-nilai kebenaran, keadilan, dan kebaikan untuk menolak segala bentuk manipulasi dan diskriminasi dalam pencapaian tujuan-tujuan muamalah. Nilai-nilai inilah yang harus dimanifestasikan dalam setiap aktivitas bisnis termasuk dalam kerangka menjaga hubungan dengan stakeholders.

Tanggung jawab sosial juga diimplementasikan untuk memenuhi syarat-syarat etika dalam kehidupan sosial masyarakat. Spektrum nilai dalam etika memiliki makna yang luas mencakup kegiatan amal (charity), kebaikan (kindness), rasa iba (compassion), kepercayaan (trust), kedermawanan (generosity), dan kepedulian terhadapkesejahteraan pihaklain (caringforthe welfare) ${ }^{15}$. Kesadaran etika manusia akan senantiasa berubah dan bersifat fluktuatif. Oleh karenanya kesadaran terhadap pemenuhan kebutuhan etika sosial dapat dilakukan melalui edukasi sekaligus implementasinya pada lingkungan sosial yang bersangkutan.

Perwujudan etika yang lain ditunjukkan oleh adanya good governance. Istilah ini mencakup apakah etika itu disebut sebagai akibat (teleological) dan disebut sebagai idealistik (deontological) ${ }^{16}$. Keputusan tentang benar atau salah didasarkan pada penilaian yang memberikan manfaat, moralitas yang berdasarkan akibat atau konsekuensi, atau oleh ketaatan terhadap aturan-aturan yang berdasarkan prinsip etika. Organisasi yang me-

${ }^{13}$ Chamhuri Siwar and Md Tareq Hossain, "An Analysis of Islamic CSR Concept and the Opinions of Malaysian Managers", Management of Environmental Quality: An International Journal, Vol. 20., No. 3, (2009), h. 292.

${ }^{14}$ Chamhuri Siwar and Md Tareq Hossain, "An Analysis of Islamic CSR Concept and the Opinions of Malaysian Managers, Management of Environmental Quality: An International Journal, Vol. 20. No. 3, (2009), h. 292.

${ }^{15}$ Srinivasan, M.S, "Values, Ethics and Wellness: An Integrated Corporate Perspective", Journal of Management, h. 135.

${ }^{16}$ Donald Norberg, D., "The Ethics of Corporate Governance", Journal of General Management, Vol. 33, No. 4, (2008), h. 42. 
miliki predikat good governance haruslah memenuhi kriteria seperti adanya keterbukaan (transparency), memiliki nilai-nilai yang jelas (organizational value), memiliki akuntabilitas yang kuat (accountability), menjamin dilaksanakannya ketentuan yang berlaku sebagai wujud tanggung jawab bank (responsibility), objektif dan bebas dari tekanan pihak manapun dalam pengambilan keputusan (independency), serta senantiasa memperhatikan kepentingan seluruh stakeholders berdasarkan asas kesetaraan dan kewajaran (fairness).

Sedangkan dalam perspektif Islam, etika dikatakan sebagai akhlak ${ }^{17}$. Etika adalah akhlak yang mencerminkan budi pekerti, tingkah laku atau tabiat seseorang. Etika dalam pengertian ini mengarahkan perilaku manusia kepada kebaikan dan kemanfaatan dalam kehidupan. Perilaku beretika dalam perspektif Islam didasarkan pada contoh-contoh perilaku Rasulullah Saw.. Sifat-sifat Rasulullah Saw. yang harus diteladani antara lain adalalah pertama: sifat yang selalu berpihak pada kebenaran dan keadilan serta sikap moral yang terpuji (shiddîq); kedua, sifat yang selalu memiliki kemauan untuk menyampaikan sesuatu dengan benar (tablìgh); ketiga, sifat yang selalu memiliki komitmen untuk melaksanakan tugas dan kewajiban yang diberikan dengan optimal, memberikan hak kepada pemiliknya, dan tidak mengambil hak yang lain (amânah); dan keempat, sifat yang mengutamakan kecerdasan akal budi dan hati dalam menjalankan tugasnya (fathânah).

Penerapan tanggung jawab sosial sebagai pemenuhan nilai etika sejalan dengan pandangan Imam al-Ghazâlî yang menyatakan bahwa pembangunan ekonomi haruslah memberikan kontribusi bagi pengembangan ilmu pengetahuan dan juga memperbaiki perilaku manusia yang sesuai dengan etika kehidupan ${ }^{18}$. Menurutnya, pembangunan ekonomi yang beretika (ethico-economic) sangat relevan dengan kehidupan di masa yang akan datang karena akan menciptakan distribusi ekonomi yang merata sehingga tidak ada ungkapan "yang kaya makin kaya, yang miskin makin miskin" (rich are getting richer while the poor getting poorer).

Paradigma ethico-economic merupakan paradigma pengembangan ekonomi berdasarkan prinsip Islam dengan memperhatikan faktor-faktor ekologis sehingga sumber daya yang ada diperlakukan secara baik dan tanpa diskriminasi ${ }^{19}$. Paradigma ini efektif jika mampu

17 Mohd. Sidi, 2008, "Etika Kerja dalam Islam", Makalah, Pusat Latihan Pengajar dan Kemahiran Lanjutan (CIAST) Jabatan Pembangunan Kemahiran Kementerian Sumber Manusia.

${ }^{18}$ Ozay Mehmet, 1997, "Al-Ghazali on Social Justice: Guidelines for a New World Order from an Early Medieval Scholar", International Journal of Social Economics, Vol. 24, No. 11, (1997), h. 1216.

${ }^{19}$ M. I., Ansari, 1991, "Methodological Foundations of Islam as an memecahkan masalah-masalah kemiskinan dan menciptkan keseimbangan dalam kehidupan manusia. Salah satu cara yang dapat dilakukan agar distribusi kemakmuran dalam masyarakat merata, maka dalam kegiatan perdagangan harus ditekankan pada implementasi tanggung jawab sosial.

Tanggung jawab sosial pada bank syariah bertujuan untuk membangun keadilan distributif. Keadilan distributif dapat dicapai bilamana kegiatan ekonomi dijalankan dengan memperhatikan faktor etika dan moralitas. Penerapan nilai etika dan moralitas pada bank syariah direpresentasikan pada dasar-dasar kegiatan bank syariah yang didasarkan pada konsep bagi hasil.

Faktor-faktor yang mendorong revitaliasi tanggung jawab sosial bank syariah sebagai tujuan integratif dikarenakan adanya "missing link" antara tujuan pengembangan bank syariah dengan implementasinya dewasa ini $^{20}$.Tidak ada keraguan terhadap perkembangan bank syariah, namun demikian faktor liberalisasi telah mempengaruhi sistem operasionalisasi bank syariah sehingga berakibat pada lemahnya perhatian terhadap bisnis skala kecil, modernisasi dan diversifikasi seperti produk derivatif yang tidak sesuai dengan prinsip Islam, dan persaingan bebas yang berdampak negatif bagi kehidupan sosial.

Islam mengajarkan keseimbangan dalam kegiatan ekonomi karena keseimbangan ekonomi berkorelasi dengan keseimbangan sosial (social equilibrium). Keseimbangan sosial tercapai bilamana tanggung jawab sosial dilaksanakan sebagai salah satu amanat kegiatan ekonomi. Jika kehidupan sosial masyarakat seimbang maka masalah sosial seperti kemiskinan, kriminalitas, dan konflik tidak akan terjadi. Allah Swt. dalam Alquran surah al-Dzâriyât [51]: 19 menerangkan tentang tanggung jawab sosial manusia sebagai berikut:

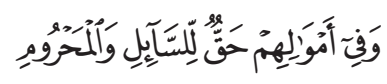

Dan pada harta-harta mereka ada hak untuk orang miskin yang meminta dan orang miskin yang tidak mendapat bagian ${ }^{21}$.

Ayat lain yang mendukung tanggung jawab sosial

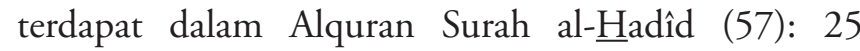
sebagai berikut:

\footnotetext{
Ethico-Economic Paradigm", Humanomics Vol. 7 (1991), h. 5.0

${ }^{20}$ Badr El Din A. Ibrahim, The "Missing Link" between Islamic Development Objectives and the Current Practice of Islamic Bankingthe Experience of the Sudanese Islamic Banks (SIBs), Humanomics, Vol. 22, No. 2, (2006), h. 64.

${ }^{21}$ Orang miskin yang tidak mendapat bagian maksudnya ialah orang miskin yang tidak meminta-minta.
} 


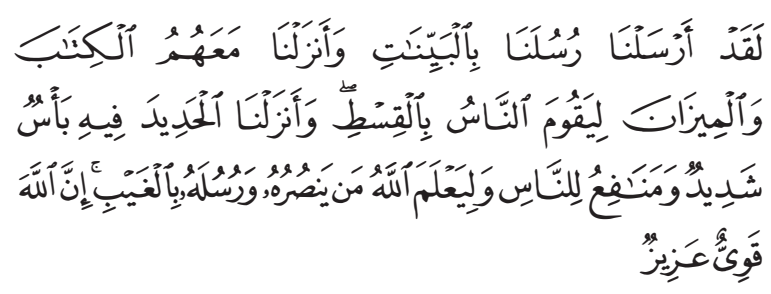

Sesungguhnya kami telah mengutus rasul-rasul kami dengan membawa bukti-bukti yang nyata dan Telah kami turunkan bersama mereka al-Kitâb dan neraca (keadilan) supaya manusia dapat melaksanakan keadilan. Dan kami ciptakan besi yang padanya terdapat kekuatan yang hebat dan pelbagai manfaat bagi manusia, (supaya mereka mempergunakan besi itu) dan supaya Allah mengetahui siapa yang menolong (agama) Nya dan rasul-rasul-Nya padahal Allah tidak dilihatnya. Sesungguhnya Allah Maha Kuat lagi Maha Perkasa.

Terdapat beberapa alasan mengapa bank syariah harus menjabarkan misi dan tujuannya dengan lebih menekankan perhatiannya pada kepentingan sosial. ${ }^{22}$ Pertama, untuk mencapai misi filosofis bank syariah yaitu "bahwa Allah Swt. sebagai Pencipta dan Pemilik dari seluruh sumber daya pada alam semesta termasuk manusia yang memiliki peran paling utama dalam mengelola sumber daya tersebut". Oleh karena itu, maka bank syariah tidak bebas bertindak sesuai dengan keinginannya saja tanpa memperhatikan nilai-nilai moralitas Islam dalam tindakan ekonomisnya.

Kedua, untuk menyediakan pembiayaan bagi siapa saja yang memiliki keahlian tetapi tidak memiliki jaminan yang memadai. Untuk mencapai tujuan tersebut maka bank syariah harus memiliki kemampuan untuk memperkuat modal sosial dalam masyarakat sebagai akar rumputnya

Ketiga, untuk menciptakan harmoni dalam masyarakat berdasar pada konsep Islam dalam semangat berbagi dan peduli sesama untuk mencapai stabilitas ekonomi, keuangan, dan politik.

\section{Legitimasi Stakeholders Bank Syariah}

Organisasi merupakan komponen dari lingkungan sosial yang besar dan bukan hanya dimiliki oleh pemilik organisasi saja. Legitimasi merupakan alat evaluasi untuk mengukur kinerja sosial sebuah organisasi. ${ }^{23}$ Legitimasi publik dapat diperoleh tidak hanya pada bagaimana sebuah organisasi menjalankan aktifitas internalnya tetapi juga dipengaruhi oleh bagaimana persepsi lingkungan terhadap tanggung jawab sosial organisasi yang bersangkutan.

${ }^{22}$ Abu Umar Faruq Ahmad dan M. Kabir Hassan, "Regulation and Performance of Islamic Banking in Bangladesh, "Thunderbird International Business Review, Vol. 49 (2), (2007), h. 261.

${ }^{23}$ S. Prakash Sethi, "Dimensions of Corporate Social Performance: An Analytical Framework", California Management Review, Vol. XVII, No. 3, (1975), h. 60.
Legitimasi stakeholder terhadap organisasi memberikan timbal balik dalam memperkuat ekuivalensi antara nilai-nilai sosial yang berhubungan dengan kegiatan operasional organisasi dan norma-norma sosial sebagai perilaku yang telah diterima secara luas oleh masyarakat sehingga harus ditaati oleh organisasi yang bersangkutan. Ukuran sebuah organisasi mendapatkan legitimasi sosial yaitu popularitas dan komitmen dari publik $^{24}$.

Stakeholder adalah individu atau kelompok yang dapat mempengaruhi atau dipengaruhi oleh tujuan organisasi..$^{25}$ Stakeholder juga dapat didefinisikan sebagai individu dan konstituen yang memberikan kontribusi baik secara sukarela maupun terpaksa dalam menciptakan kapasitas dan aktivitas yang mengarah pada kemakmuran dan mereka mendapatkan keuntungan dan atau risiko karena aktivitas organisasi ${ }^{26}$.

Kepentingan seluruh stakeholder memiliki nilai intrinsik dan kepentingan-kepentingan tersebut tidak diarahkan untuk melakukan dominasi satu sama lain. Dengan demikian pengelola organisasi terutama organisasi bisnis harus menjamin bahwa hak-hak etis seluruh stakeholder diberikan perhatian secara seimbang sehingga tujuannya dalam memaksimalkan kemakmuran jangka panjang dapat tercapai.

Stakeholder dibagi menjadi dua yaitu stakeholder primer dan stakeholder sekunder ${ }^{27}$. Stakeholder primer merupakan pihak yang memiliki hubungan kontraktual langsung dengan perusahaan atau disebut sebagai contractual stakeholders. Sedangkan pihak-pihak yang dapat dipengaruhi oleh tindakan atau kegiatan perusahaan tanpa memiliki ikatan kontraktual disebut sebagai stakeholder sekunder atau diffuse stakeholders.

Stakeholder dapat diklasifikasikan menjadi beberapa kategori, antara lain:28 (1) Stakeholder primer, yaitu pihak-pihak yang terlibat secara langsung dan memiliki hubungan kontraktual dengan organisasi; (2) Stakeholder sekunder, yaitu pihak-pihak yang dapat terkena dampak dari operasionalisasi organisasi dan tidak memiliki hubungan kontraktual.

${ }^{24}$ Enrique Bonsón dan Melinda Ratkai, "A Set of Metrics to Asses Stakeholder Engagement and Social Legitimacy on a Corporate Facebook Page", Online Information Review, Vol. 37, No. 5, h. 793.

${ }_{25}$ R. Edward Freeman, Strategic Management: A Stakeholder Approach, (Boston : Pitman Press, 1984), h. 43.

${ }^{26}$ J. E., Post, L. E. Preston, dan S. Sach, "Managing the Extended Entreprise: the New Stakeholder View", California Management Review, Vol. 45, (2002), h. 6.

${ }^{27}$ A. B., Carroll, 1989, Business and Society: Ethics and Stakeholder Management, (South Western, Cincinnati , 1989), h. 22.

${ }^{28}$ Yves Fassin,"Stakeholder Management, Reciprocity and Stakeholder Responsibility", Journal of Business Ethics 109, (2012), h. 84. 
Hubungan pengelola organisasi dan stakeholder itu sendiri terfokus pada tiga hal yaitu hubungan deskriptif, normatif dan instrumental. ${ }^{29}$ Hubungan deskriptif menggambarkan bagaimana pengelola berhadapan dengan stakeholder, hubungan normatif menjelaskan bagaimana seharusnya pengelola berhadapan dengan stakeholder, dan hubungan instrumental mendeskripsikan apa yang terjadi jika pengelola memperlakukan stakeholder dengan cara-cara yang tepat.

Stakeholder bank meliputi pemilik, manajer, peminjam, deposan, dan pengambil kebijakan. ${ }^{30}$ Masingmasing pihak memiliki ekspektasi yang berbeda terhadap bank. Jika pemilik atau investor memiliki harapan terhadap peningkatan kemakmurannya, sementara nasabah dan deposan memiliki harapan mendapatkan perlakuan yang adil dan transparan baik dalam penerimaan keuntungan (return) maupun risiko (risk). Lembaga keuangan sebagai intermediaris penting dalam perekonomian berada pada nexus relasi khusus dengan pelbagai jenis stakeholder berbeda yang dapat menekan intitusi baik akibat regulasi maupun akibat lainnya. Oleh karena itu posisi realisasi tanggung jawab sosial menjadi salah satu kegiatan penting bagi tercapainya kesesuaian harapan antara bank dengan stakeholder.

Jika dikaitkan dengan teori stakeholder dalam perspektif Islam maka kualifikasi stakeholder adalah mereka yang hak dan kepemilikannya dipertaruhkan atau terkena risiko (at stake) sebagai akibat dari tindakan perusahaan yang sengaja atau tidak sengaja. Perspektif ini menegaskan bahwa pengelola perusahaan diharapkan melindungi kepemilikan dari pemegang saham, pihak yang berpartisipasi dalam operasional perusahaan, dan pihak-pihak yang kepemilikannya terancam olehnya ${ }^{31}$.

Stakeholder baik yang memiliki hubungan kontraktual langsung maupun tidak memiliki hak untuk mendapatkan perhatian. Kerangka Islam tentang kontrak memberikan tekanan yang sama atas kewajiban baik yang berasal dari kontrak implisit maupun eksplisit. Ketentuan tentang hubungan kontraktual bertujuan untuk memberikan perlindungan kepada pihak yang mengikat kontrak dan terutama untuk menghindari dampak risiko ekstrem yang mungkin timbul. Selain itu, tujuan perlindungan kepentingan stakeholder juga bertujuan untuk tercapainya keadilan yang merupakan wujud keseimbangan pada pelbagai sisi yang harus

${ }^{29}$ T. M. Jones, 1995, "Instrumental Stakeholder Theory", Academy of Management Review, Vol. 20, No. 2, (1995), h. 406.

${ }^{30}$ Sibel Yamak and Ömür Süer, "State as a Stakeholder", Corporate Governance Vol. 5, No. 2, (2005), h. 114.

${ }^{31}$ Z. Iqbal dan A. Mirakhor, Pengantar Keuangan Islam: Teori dan Praktik, diterjemahkan oleh A. K. Anwar, (Jakarta: Kencana, 2008), h. 386 . dipenuhi baik sisi finansial, komitmen moral dan tanggung jawab sosial. Sehingga kepentingan stakeholder dalam perspektif Islam menjadi bagian dari konstruksi kepentingan yang menggambarkan keseimbangan dan harmoni diantara pelbagai kelompok berdasarkan etika dan prinsip moralitas berlandaskan aturan syariat Islam.

Bagi bank syariah, eksistensi stakeholder penting bagi tercapainya misi bank yang mencakup kepatuhan pada prinsip-prinsip syariah dan penyediaan pelayanan yang terbaik $^{32}$. Kepatuhan syariah menentukan tercapainya tiga hal penting. Pertama, pemahaman terhadap keterjagaan perilaku bisnis keuangan agar tidak melanggar riba dan gharâr. Kedua, pencapaian tujuan sosial yang menjadi pondasi Islam terutama bagi tercapainya kesalehan sosial yang adil. Ketiga, komitmen terhadap tercapainya konstruksi sistem keuangan syariah yang berkembang sebagai sistem yang terintegrasi. Sedangkan tujuan pelayanan mencakup pelayanan yang bersifat inklusif bagi umat Islam dan juga bagi stakeholder baik stakeholder primer maupun stakeholder sekunder.

Islam melihat stakeholder dengan mempertimbangkan realitas bahwa pemilik memiliki hak untuk mengambil keuntungan tetapi tidak dapat membebankan biaya tersebut kepada stakeholder ${ }^{3}$. Dalam rangka menjaga hubungan baik antara pemilik dengan stakeholder maka Islam juga mengaturnya kedalam norma-norma tertentu. Norma bisnis yang terefleksikan dalam etika bisnis Islam tersebut bersumber dari Alquran, Sunah, dan konsensus para ulama.

Stakeholder bank syariah meliputi ${ }^{34}:$ (1) Customer, pihak yang mendapatkan pembiayaan dari bank syariah baik sedang maupun pernah mendapatkan pembiayaan; (2) Deposan, pihak yang menempatkan dananya pada pelbagai jenis produk bank syariah; (3) Komunitas lokal, pihak yang tidak memiliki hubungan langsung dengan bank; (4) Karyawan, pihak yang bekerja pada bank syariah tetapi tidak termasuk manajer; (5) Manajer, seluruh manajer yang berperan dalam mengkoordinasi seluruh kegiatan bank syariah; (6) Pengambil kebijakan, pihak yang memiliki tanggung jawab dalam hal regulasi dan pengawasan (di Indonesia dilakukan oleh Bank Indonesia dan Otoritas Jasa Keuangan); (7) Dewan Pengawas Syariah, pihak-pihak yang memiliki keahlian

${ }^{32}$ Man Al Abdullah, Corporate Governance Perbankan Syariah di Indonesia, (Jogjakarta: Ar-Ruzz Media, 2010), h. 48

33 Rafik I. Beekun dan Jamal A. Badawi, "Balancing Ethical Responsibility among Multiple Organizational Stakeholders: The Islamic Perspective", Journal of Business Ethics 60, (2005), h. 132

${ }^{34}$ Asyraf Wajdi Dusuki, "Understanding the Objectives of Islamic Banking: a Survey of Stakeholders' Perspectives", International Journal of Islamic and Middle Eastern Finance and Management, Vol. 1, No. 2, (2008), h 138. 
untuk menentukan tingkat kesyariah-an produkproduk bank syariah.

Tindakan yang harus dilakukan oleh bank agar mendapatkan legitimasi stakeholder berdasarkan maqashid syariah dan etika bisnis Islam meliputi beberapa prinsip. ${ }^{35}$ Pertama, prinsip keadilan ('adl). Adil (justice) berkaitan dengan kesetaraan (equality) dan keseimbangan (balance). Dalam Islam, setiap umat harus berperilaku seuai dengan nilai-nilai keislaman. Adil merupakan bentuk keseimbangan yang proporsional dan penghindaran terhadap hal-hal ekstrim sehingga terbentuklah harmoni yang universal dalam kehidupan manusia. Keadilan tercapai bilamana setiap individu atau organisasi memiliki kemampuan untuk menjaga kebutuhan diri, pikiran, dan jiwa sebagaimana dalam Alquran Surah al-Nahl (16): 90 sebagai berikut:

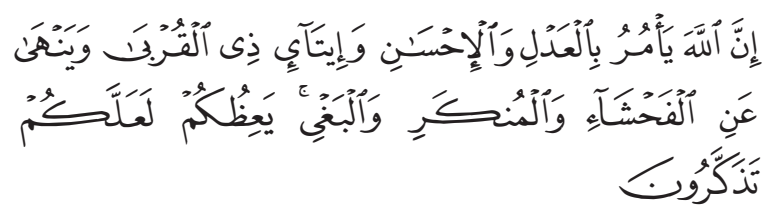

Sesungguhnya Allah menyuruh (kamu) berlaku adil dan berbuat kebajikan, memberi kepada kaum kerabat, dan Allah melarang dari perbuatan keji, kemungkaran dan permusuhan. Dia memberi pengajaran kepadamu agar kamu dapat mengambil pelajaran.

Adil dalam Alquran juga diterjemahkan sebagai "qist" yaitu spirit untuk berbagi segala sesuatu kepada sesama manusia karena Allah Swt. menyukai sikap adil sebagaimana diterangkan dalam Q.s al- Hujurât (49): 9.

Kedua, prinsip tanggung jawab (amânah). Setiap diri bertanggung jawab terhadap tindakannya. Amanah merupakan perwujudan sikap yang sesuai dengan moralitas Islam. Islam menegaskan bahwa kekayaan dan sumber daya yang dimiliki oleh seseorang sesungguhnya bukanlah miliknya, melainkan milik Allah Swt. Oleh karena itu, setiap diri memiliki tanggung jawab baik terhadap dirinya, lingkungannya, maupun kepada Sang Khaliq sebagaimana diterangkan dalam Alquran surah al-Muddatstsir (74): 38 sebagai berikut:

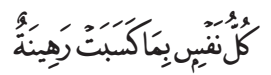

Tiap-tiap diri bertanggung jawab atas apa yang telah diperbuatnya.

Ketiga, prinsip kebajikan (I $\underline{h} s a n)$. Sikap adil adalah kewajiban (mandat), sedangkan ihsan merupakan hal yang melebihi mandat ${ }^{36}$. Adil mensyaratkan konsistensi

${ }^{35}$ Asyraf Wajdi Dusuki, "Understanding the Objectives of Islamic Banking: a Survey of Stakeholders' Perspectives", International Journal of Islamic and Middle Eastern Finance and Management, Vol. 1, No. 2, (2008), h. 134

${ }^{36}$ Al-Qurthubî dan Abî 'Abd Allâh al-Anshârî, Al-Jâmi' li A $\underline{h} k a ̂ m$ al-Qur'ân, (Beirut: Dâr al-Turâts al-'Arabî, 1996), h. 10. ucapan dan perilaku, sedangkan ihsan mensyaratkan perilaku manusia lebih dari yang terlihat secara lahiriah dalam ucapan dan tindakan. Sikap ini juga merupakan sikap yang didasarkan pada kepedulian terhadap sesama dan kecintaan terhadap Allah Swt. Sikap ihbsan dalam implementasi pengelolaan organisasi dicerminkan pada upaya yang sungguh-sungguh dan optimal untuk memberikan layanan terbaik bagi stakeholder dan masyarakat. Sikap ihsan diterangkan dalam Alquran surah al Kahfi (18): 30 sebagai berikut:

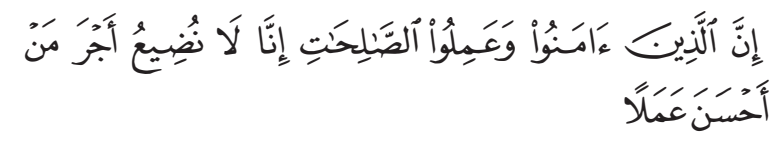

Sesungguhnya mereka yang beriman dan beramal saleh, tentulah kami tidak akan menyia-nyiakan pahala orangorang yang mengerjakan amalan (nya) dengan yang baik.

\section{Implementasi Tanggung Jawab Sosial Bank Sya- riah Dewasa ini}

Bank syariah memiliki kewajiban untuk mengungkapkan informasi secara tepat waktu, memadai, jelas, akurat, dan dapat diperbandingkan serta mudah diakses oleh stakeholder. Informasi yang harus diungkapkan bersifat tidak terbatas pada hal-hal yang bertalian dengan visi, misi, sasaran usaha dan strategi perusahaan, kondisi keuangan, susunan dan kompensasi pengurus, pemegang saham pengendali, dan pihak lain. Namun, demikian prinsip keterbukaan dalam informasi yang dianut oleh bank tidak mengurangi kewajiban untuk memenuhi ketentuan rahasia bank sesuai dengan peraturan perundang-undangan yang berlaku, rahasia jabatan, dan hak-hak pribadi.

Demikian pula tanggung jawab sosial bank syariah juga harus dapat diwujudkan melalui pelaporan sosial (social reporting). Prinsip tanggung jawab dilakukan dalam rangka: (1) untuk menjaga kelangsungan usaha bank syariah dengan tanpa mengabaikan prinsip kehati-hatian dan ketentuan-ketentuan yang berlaku; dan (2) bank bertindak sebagai good corporate citizen atau sebagai perusahaan yang baik, termasuk peduli terhadap lingkungan dan melaksanakan tanggung jawab sosial. Adapun pelaporan sosial dalam perspektif Islam meliputi beberapa aspek. ${ }^{37}$ Pertama, akuntabilitas (accountability). Prinsip akuntabilitas meliputi: (1) tanggung jawab bank dalam menetapkan strategi perusahaan; (2) bank harus meyakini bahwa semua organ bank mempunyai kompetensi sesuai dengan

${ }^{37}$ Umaru Mustapha Zubairu, Olalekan Busra Sakariyau, dan Chetubo Kuta Dauda, "Social Reporting Practices of Islamic Banks in Saudi Arabia", International Journal of Business and Social Science, Vol. 2, No, 23, (2011), h. 196 
tanggung jawabnya dan memahami perannya dalam pelaksanaan GCG; (3) bank harus memastikan terdapatnya check and balance system dalam pengelolaan bank; dan (4) bank harus memiliki ukuran kinerja dari semua jajaran bank yang berjalan berdasarkan ukuranukuran yang disepakati konsisten dengan nilai-nilai perusahaan, sasaran usaha dan strategi bank, serta memiliki reward and punishment system.

Kedua, keadilan sosial (social justice). Keadilan sosial dalam hal ini mengandung makna pemerataan pada distribusi pendapatan terhadap masyarakat sehingga kebutuhannya tercukupi. Keadilan sosial dalam Islam mencakup kondisi yang lebih luas dimana keadilan sosial tercapai tidak hanya pada pemerataan pendapatan tetapi juga pada pembangunan nilai-nilai moralitas Islam. Oleh karena itu, pelaporan tanggung jawab sosial bank syariah hendaklah diarahkan pada pengungkapan perannya dalam membangun nilai-nilai tersebut.

Ketiga, kepemilikan (ownership) dan kepercayaan (trust). Pelaporan tanggung jawab sosial menggambarkan kepemilikan terhadap aset institusional dan juga kepercayaan masyarakat terhadap institusi yang bersangkutan. Namun demikian pelaporan tersebut dalam perspektif Islam tidak boleh mengabaikan bahwasanya bumi, langit, dan seisinya adalah milik Allah Swt. sebagaimana tercantum dalam Alquran Surah Ali 'Imran [3]: 189:

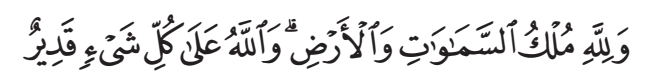

Kepunyaan Allah-lah kerajaan langit dan bumi, dan Allah Maha Perkasa atas segala sesuatu

Implementasi tanggung jawab sosial dapat diketahui stakeholder melalui laporan keuangan. Laporan keuangan yang baik adalah laporan keuangan yang menggambarkan keseluruhan aktivitas bank baik aktivitas ekonomi maupun sosial. Esensi laporan keuangan tidak semata-mata untuk mengetahui posisi keuangan, aliran kas, dan profitabilitas bank tetapi memberikan informasi yang menyeluruh baik tentang kinerja bank, prospeknya di masa yang akan datang, dan seberapa besar kontribusinya bagi upaya-upaya peningkatan kesejahteraan umat.

\section{Penutup}

Tujuan bank syariah sejalan dengan tujuan ekonomi Islam yaitu tercapainya tujuan material dalam tatanan kehidupan dunia dan kehidupan spiritual sebagai bekal kehidupan akhirat. Untuk mencapai tujuan tersebut, pengelolaan bank syariah tidak diarahkan sematamata pada upaya memaksimalkan profit tetapi juga berkontribusi aktif dalam menciptakan kesejahteraan sosial, penghapusan kemiskinan, dan sistem edukasi dalam menjalankan nilai-nilai keislaman.

Tanggung jawab sosial didesain sebagai jembatan antara bank syariah dengan masyarakat dalam mewujudkan maqâshid syarî‘ah. Keadilan distributif sebagai tujuan akhir dapat dicapai dengan memperhatikan faktor-faktor etika dan moralitas Islam. Prinsip keadilan ('adl), tanggung jawab (amanah), dan kebajikan (ihsan) merupakan prinsip-prinsip dasar dalam pengembangan tanggung jawab sosial. Adil merupakan bentuk keseimbangan yang proporsional dan penghindaran terhadap hal-hal ekstrem sehingga terbentuklah harmoni yang universal dalam kehidupan manusia. Amanah adalah perwujudan sikap yang sesuai dengan moralitas Islam yang menegaskan bahwa kekayaan dan sumber daya yang dimiliki oleh seseorang sesungguhnya bukanlah miliknya, melainkan milik Allah Swt. Sedangkan ihsan merupakan sikap yang didasarkan pada kepedulian terhadap sesama dan kecintaan terhadap Allah Swt. dan tercermin pada upaya yang sungguh-sungguh dan optimal untuk memberikan layanan terbaik bagi stakeholder dan masyarakat.

Implementasi tanggung jawab sosial diinformasikan kepada stakeholder dan masyarakat dalam bentuk pelaporan sosial. Laporan tersebut mendeskripsikan tentang aktifitas bank syariah dalam memberdayakan masyarakat dan kegiatan-kegiatan amaliah lain di setiap periodenya. Pelaporan sosial dalam perspektif Islam mencakup akuntabilitas bank syariah, keadilan sosial, kepemilikan, dan tingkat kepercayaan konsumen terhadap bank syariah.

Dimensi sosial dalam implementasi perbankan syariah didasarkan pada Alquran dan dikembangkan bagi kemaslahatan seluruh umat manusia. Ketiadaan peran sosial bank syariah dapat mereduksi kesakralan sistem ekonomi Islam yang diyakini mampu mengatasi problem ekonomi yang ditumbulkan oleh sistem kapitalisme seperti kemiskinan, pengangguran, dan masalah sosial ekonomi lainnya. Transfer kekayaan dari si kaya ke si miskin pada dasarnya dapat dikelola dan diadministrasikan sehingga kegiatan amal dan tanggung jawab sosial mudah untuk dievaluasi dan diperbaiki secara kontinyu. []

\section{Pustaka Acuan}

Abdullah, M. A., Corporate Governance Perbankan Syariah di Indonesia, Jogjakarta: Ar-Ruzz Media, 2010.

Ahmad, A. U. F., dan Hassan, M. K., "Regulation and Performance of Islamic Banking in Bangladesh", Thunderbird International Business Review, Vol. 49 (2), 2007.

Aliyu, S., "Sustainable Islamic Banking: A Conceptual 
Framework for Non-Interest Banks in Nigeria", International Journal of Economics, Management, and Accounting 22, No. 1, 2014.

Al-Qurtubi dan Abi Abdullah Al-Ansari, Al Jami' Li Ahkam Al-Qur'an, Beirut: Dar Al-Turaath Al-Arabi, 1966.

Ansari, M. I., "Methodological Foundations of Islam as an Ethico-Economic Paradigm", Humanomics Vol. 7, 1991.

Beekun, R. I. dan Badawi, J. A., "Balancing Ethical Responsibility among Multiple Organizational Stakeholders: The Islamic Perspective", Journal of Business Ethics 60, 2005.

Bonsón, E. dan Ratkai, M., "A Set of Metrics to Asses Stakeholder Engagement and Social Legitimacy on a Corporate Facebook Page," Online Information Review, Vol. 37, No. 5, 2013.

Carroll, A. B., Business and Society: Ethics and Stakeholder Management, South Western, Cincinnati, OH, 1989.

Chapra, M. U., "The Global Financial Crisis Can Islamic Finance Help?", Insight 01: 4, 2009.

Departemen Agama, Al Qur'an dan Terjemahnya, Yayasan Penyelenggara Penterjemah/Penafsir, 1971.

Dusuki, A. W., "Understanding the Objectives of Islamic Banking: a Survey of Stakeholders' Perspectives, International Journal of Islamic and Middle Eastern Finance and Management, Vol. 1, No. 2, 2008.

Fassin, Y.,"Stakeholder Management, Reciprocity and Stakeholder Responsibility", Journal of Business Ethics 109, 2012.

Freeman, R. E., Strategic Management: A Stakeholder Approach, Boston, MA : Pitman Press, 1984.

Ibrahim, B. E., "The 'Missing Link' between Islamic Development Objectives and the Current Practice of Islamic Banking - the Experience of the Sudanese Islamic Banks (SIBs), Humanomics, Vol. 22, No. 2, 2006.

Iqbal, Z., dan Mirakhor, A., Pengantar Keuangan Islam: Teori dan Praktik, diterjemahkan oleh A. K. Anwar, Jakarta : Kencana, 2008.

Jones, T. M., 1995, "Instrumental Stakeholder Theory", Academy of Management Review, Vol. 20, No. 2, 1995.

Karim, R. A. A., "The Independence of Religious and External Auditors: The Case of Islamic Banks", Accounting Auditing and Accountability Journal, 3(3), 1990.
Khan, M. U., Halabi, A. K., dan Samy, M., "Corporate Social Responsibility (CSR) Reporting: a Study of Selected Banking Companies in Bangladesh", Social Responsibility Journal, Vol. 5, No. 3, 2009.

Lewis, B., 1993, Islam and West, Oxford University Press, 1993.

Mehmet, O., 1997, Al-Ghazâlî on Social Justice: Guidelines for a New World Order from an Early Medieval Scholar, International Journal of Social Economics, Vol. 24, No. 11, 1997.

Misanam, M., Suseno, P., dan M. dan Hendrieanto, M. B., Ekonomi Islam, Jakarta : PT RajaGrafindo Perkasa, 2008.

Norberg, D., The Ethics of Corporate Governance, Journal of General Management, Vol. 33, No. 4, 2008.

Post, J. E., Preston, L. E., dan Sach, S., "Managing the Extended Entreprise: the New Stakeholder View," California Management Review, Vol. 45, 2002.

Rosly, S. A., dan Zaini, M. A., Risk-Return Analysis of Islamic Banks' Investment Deposits and Shareholders' Fund, Managerial Finance, Vol. 34, No. 10, 2008.

Sethi, S. P., "Dimensions of Corporate Social Performance: An Analytical Framework", California Management Review, Vol. XVII, No. 3, 1975.

Sidi, M., "Etika Kerja dalam Islam", Makalah, Pusat Latihan Pengajar dan Kemahiran Lanjutan (CIAST) Jabatan Pembangunan Kemahiran Kementerian Sumber Manusia, 2008.

Siwar, C., dan Hossain, M. T ,'An Analysis of Islamic CSR Concept and the Opinions of Malaysian Managers," Management of Environmental Quality: An International Journal, Vol. 20., No. 3, 2009.

Srinivasan, M.S, "Values, Ethics and Wellness: An Integrated Corporate Perspective", XIMB Journal of Management, 2010.

Warde, I., Islamic Finance: Keuangan Islam dalam Perekonomian Global, Penerjemah: Andriyadi Ramli, Yogyakarta: Pustaka Pelajar, 2009.

World Islamic Banking Competitiveness Report, 20132014

Yamak, S., dan Süer, Ö, "State as a Stakeholder", Corporate Governance Vol. 5, No. 2, 2005.

Zubairu, M. U., Sakariyau, O. B., dan Dauda, C. K., "Social Reporting Practices of Islamic Banks in Saudi Arabia, International Journal of Business and Social Science, Vol. 2, No, 23, 2011. 